\title{
The Effect of Professional Ethics Program (in-Personal and E-learning) on Nurses' Performance and Satisfaction of Patients Referring to Emergency Department of Hospitals Affiliated to Armed Forces
}

\author{
Foroughi. $\mathrm{L}^{1}$ \\ *Zareiyan. $\mathrm{A}^{2}$ \\ Sharififar. $\mathrm{S}^{3}$ \\ 1- MSc Student of Emergency \\ Nursing, Faculty of Nursing, \\ Aja University of Medical \\ Sciences, Tehran, Iran. \\ 2- ( ${ }^{*}$ Corresponding Author) \\ Ph.D., in Nursing Education, \\ Associate Professor, Health \\ Department, Faculty of \\ Nursing, Aja University of \\ Medical Sciences, Tehran, \\ Iran. \\ Email: arminzj@yahoo.com \\ 3- Ph.D., Health in Disasters and \\ Emergency, Instructor, Health \\ in Disasters and Emergency \\ Department, Faculty of \\ Nursing, Aja University of \\ Medical Sciences, Tehran, \\ Iran.
}

\begin{abstract}
Introduction: Rationality and ethics are essential in the jobs which serve the people. The nursing with many moral aspects plays a key role in implementing a health care system.

Objectives: The aim of this study was to determine the effect of professional ethics program (in person and e-learning) on ethical performance of nurses in the emergency ward of armed forces -dependent hospitals..

Materials and Methods: The present study was a semi-experimental and prepost-test study done on a control group in 2018 in three stages including before the intervention, after intervention and one month after intervention. Three groups (Control, face to face training and E-learning) were evaluated using the questionnaire of nurses' ethical performance.A one-day workshop for in-person group and Shahab site e-learning for virtual education were arranged.. In the present study, sample population included nurses in the emergency ward of two selected armed forces hospitals in Tehran who are eligible and have inclusion criteria. After filling in the questionnaires, the data were analyzed in three stages using SPSS $25(\mathrm{P}<0.001)$.
\end{abstract}

Results: The results of the study showed that there was no significant difference in the ethical performance of nurses before the intervention in the pre-test between the three groups. While there was a statistically significant difference in the in-person training and virtual education groups in the first and second post-tests, but a higher statistically significant difference observed in the in-person training group.

Discussion and Conclusion: Considering the positive effects of professional ethics training to improve the ethical performance of emergency ward nurses, it is suggested that different training and planning methods be used to improve the status quo. However, based on the results of the study, in-person training is prioritized.

Keywords: Emergency Service, E-learning, Virtual Education, Nurses Ethical Performance, Professional Ethics, Training. 


\title{
تأثير بر نامه اخلاق حرفهاى (حضورى و الكترونيك) بر عملكرد اخلاقى برستاران بخش اورزانس بيمار ستانهاى تابعه نيروهاى مسلح
}

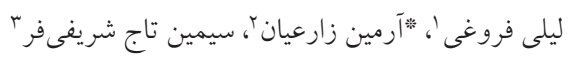

جكيده

مقدمه: عقلانيت و اخلاق از ضروريات مشاغلى است كه به انسانها ارائه خدمت مىكنند. حرفه يرستارى با بسيارى از جنبههاى اخلاقى نقش كليدى در اجراى يك سيستم مراقبت بهداشتى ايفا مى كند. هدف: اين مطالعه با هدف تعيين تأثير برنامه اخلاق حرفهاى (حضورى و الكترونيك) بر عملكرد اخلاقى يرستاران بخش إنش اورزانس بيمارستانهاى تابعه نيروهاى مسلح انجام شده است.

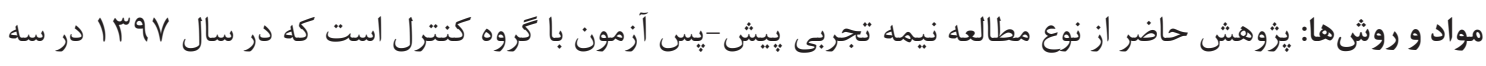

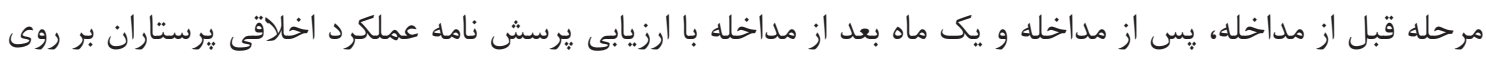

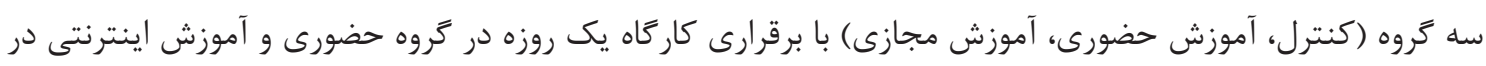

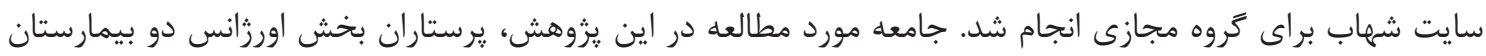

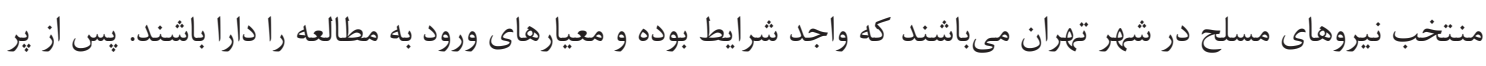

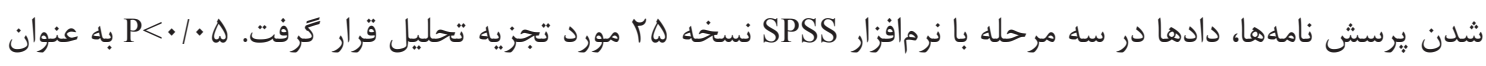
سطح معنى دارى در نظر كرفته شد.

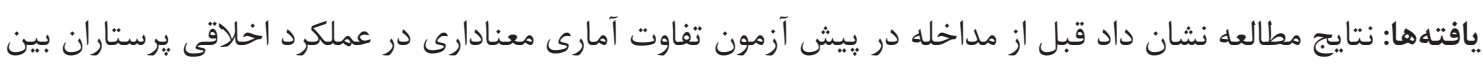

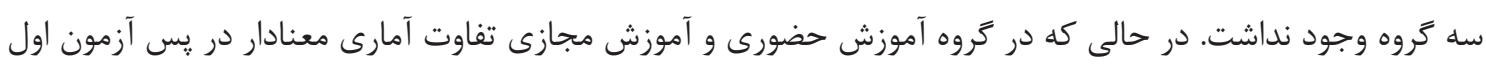

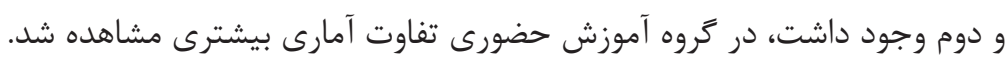

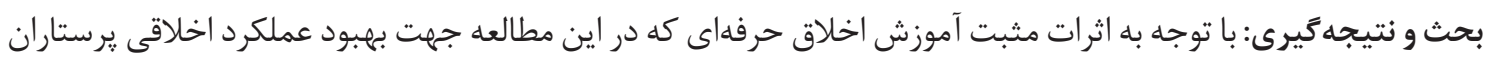

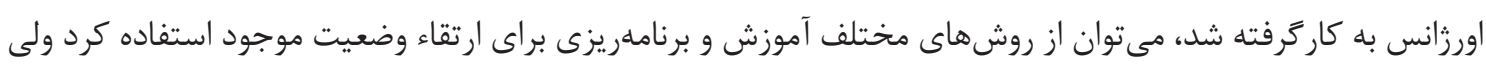

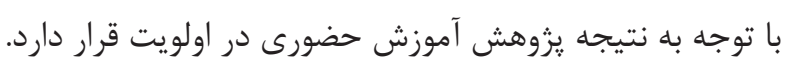

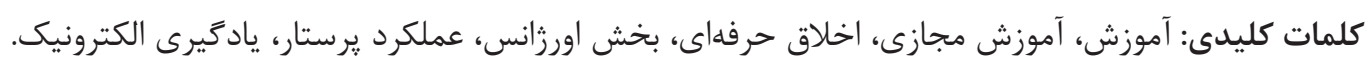

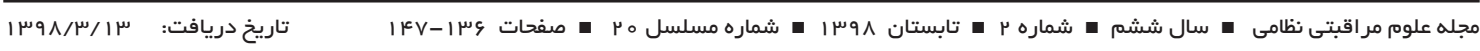

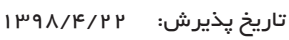

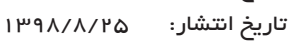

كوناگونى با عنوان كدهاى اخلاق حرفهاى تدوين شده كه بايد مقدمه

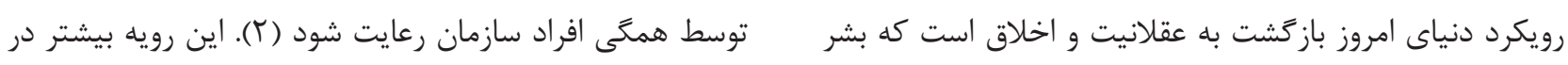

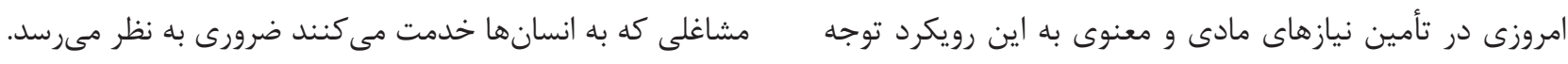

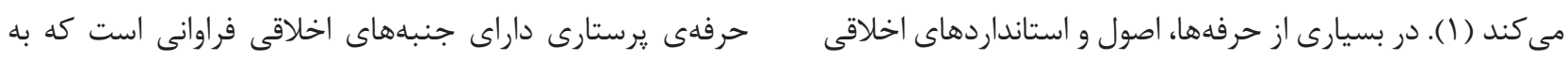


نياز است؛ بنابراين مداخلات، براى پِيدا كردن بهترين روشها و

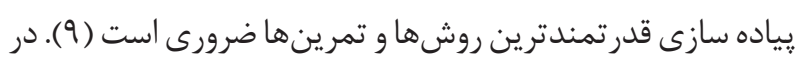
حال حاضر آموزش مجازى يكى از محيطهاى مههم آموزشى است.

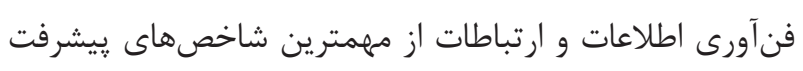

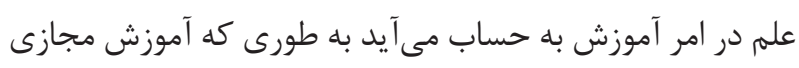

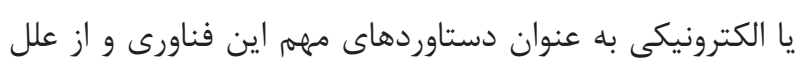
اصلى ييشرفتهاى علمى، يزوهشى و فرهنتى حال حاضر است.

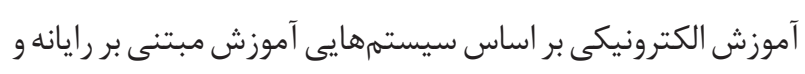

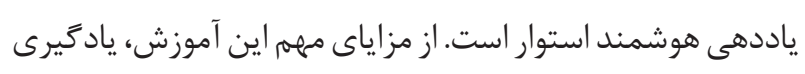

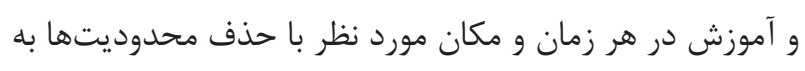

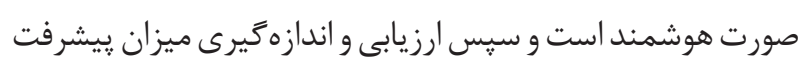

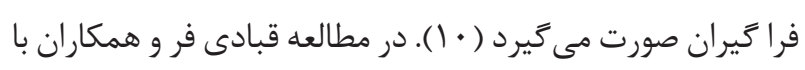

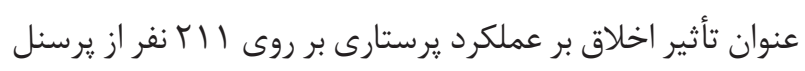

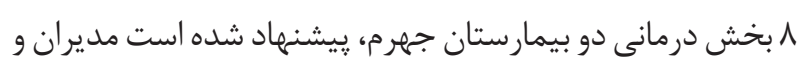

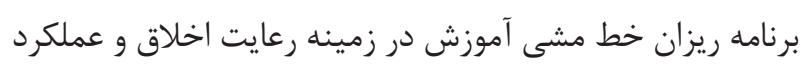

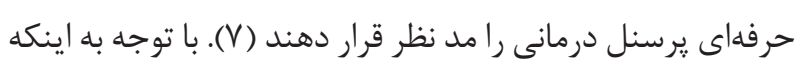

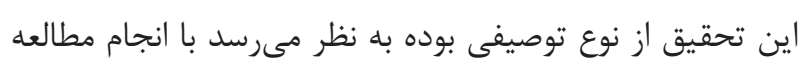

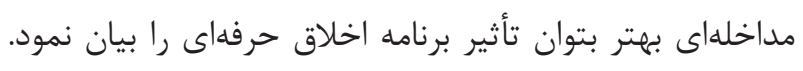

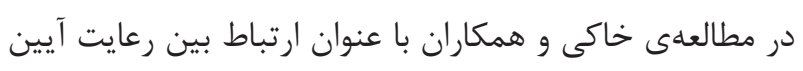

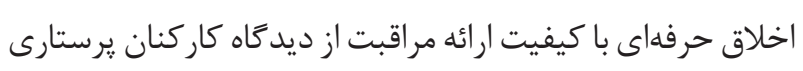

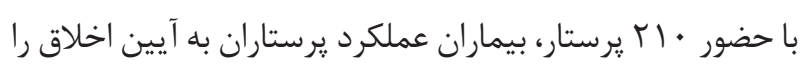

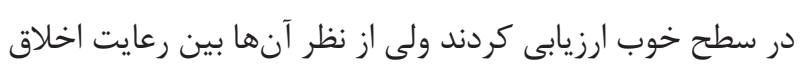

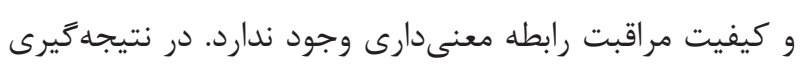
بر ضرورت عملكرد اخلاقى به عنوان يكى از مؤلفههاى اصلى ارائه

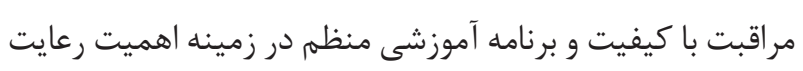
اصول اخلاق يرستارى با رويكرد مددجو محورى در بيمارستانها

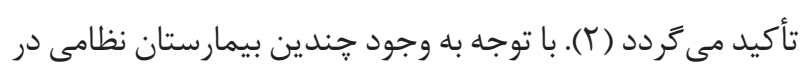
شهر تهران بررسى برنامه اخلاق و تأثير آن بر بيماران اين مراكز

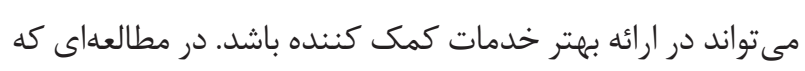

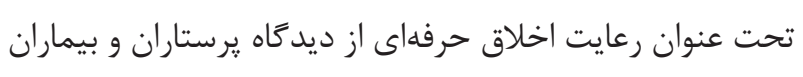

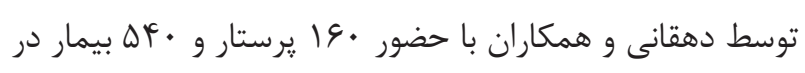
شهر جهرم انجام شد، يافتهها نشان داد بين دو ديدكاه يرستاران

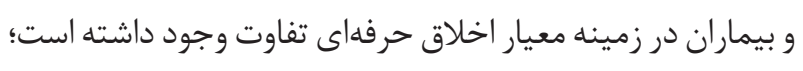
بنابراين ييشنهاد مىشود با آموزش كادر درمانى و افزايش آكاهي
عنوان وجدان سيستم مراقبت بهداشتى شناخته شده و نقش داء

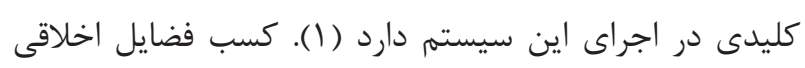

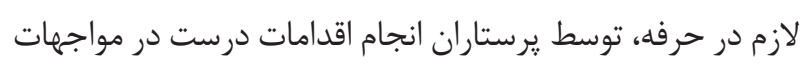

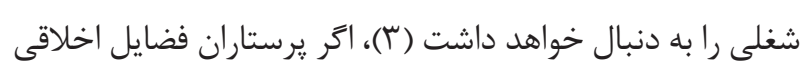

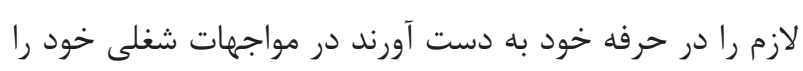

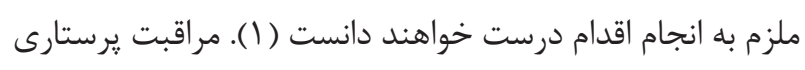

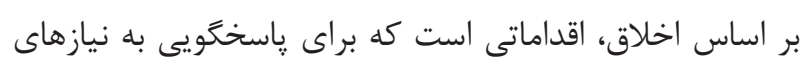

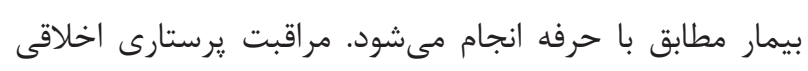

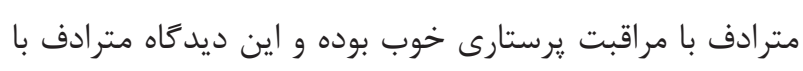

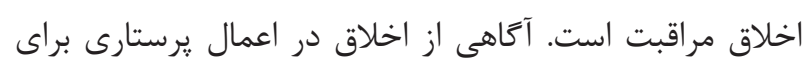

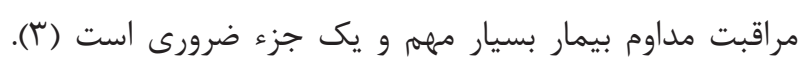

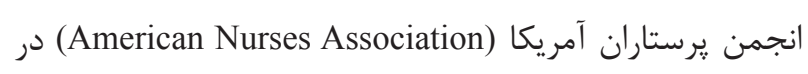

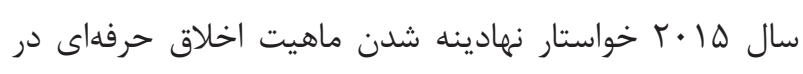

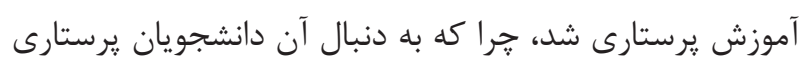

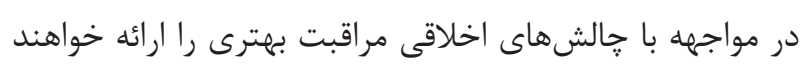

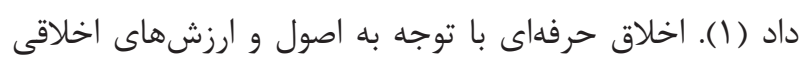

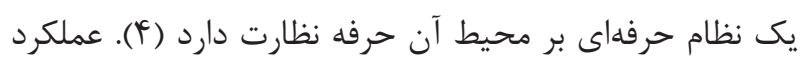

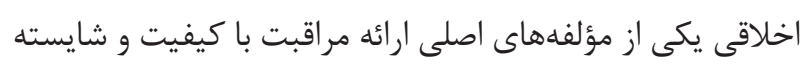

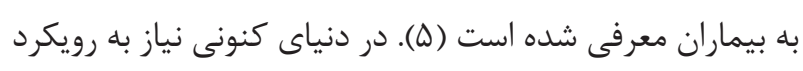

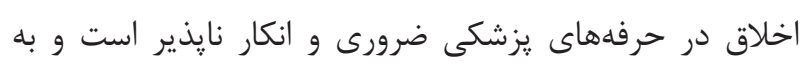

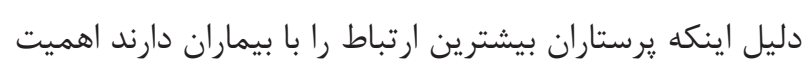

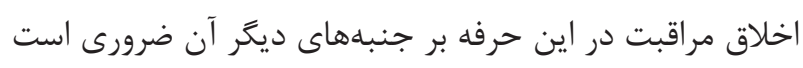

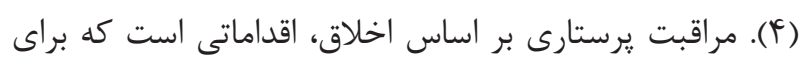

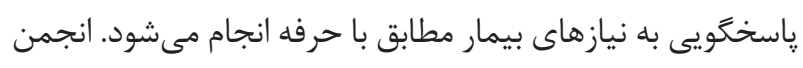

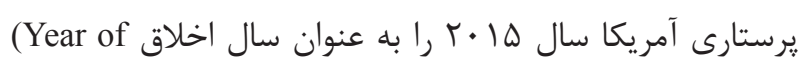
تعthics)

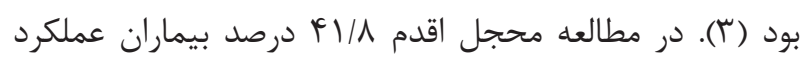
يرستاران به آيين اخلاق رادر سطح خوب دانستهاند (ع). قبادى درف

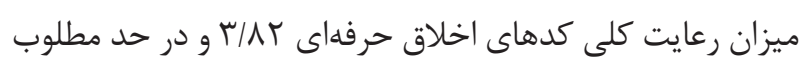

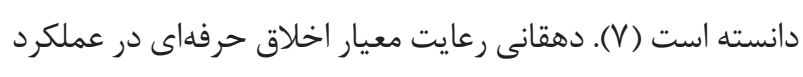

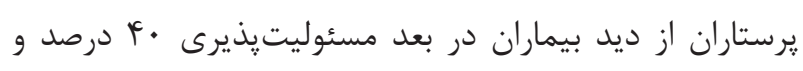

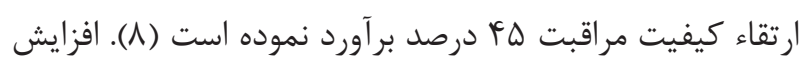
و بهبود آكاهى هاى اخلاقى مطابق با خواستههاى بيمار ضرورى

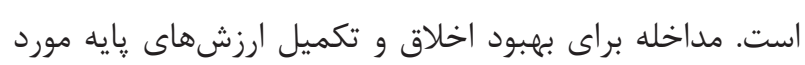


در بيمارستانهاى منتخب نيروهاى مسلح در دو كروه آزمون و

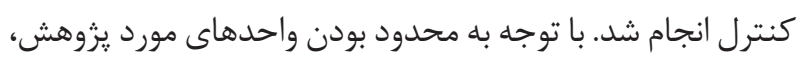

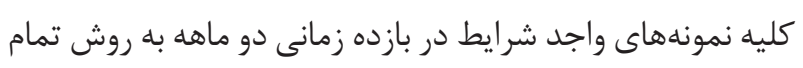

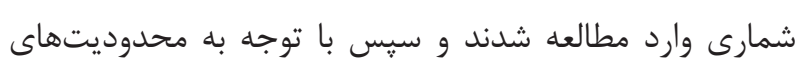

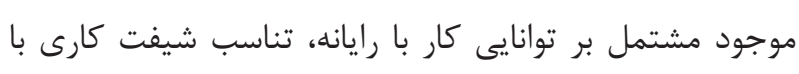

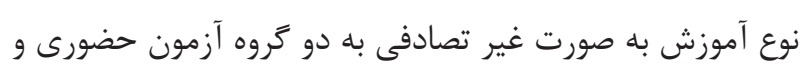

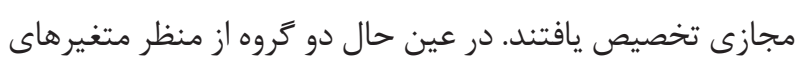
احتمالى مداخلهَر (نظير سن، نوع بيمارى و...) قبل از مداخله

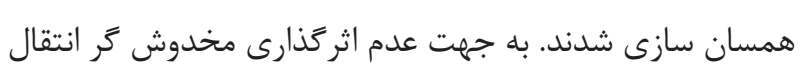
اطلاعات يرستاران كروه كنترل از بيمارستان نظامى ديخرى كه

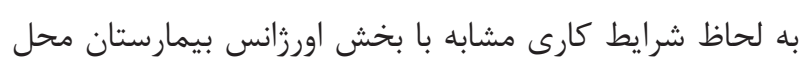

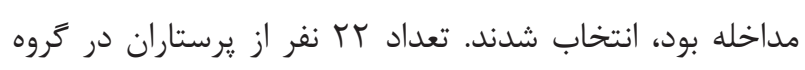

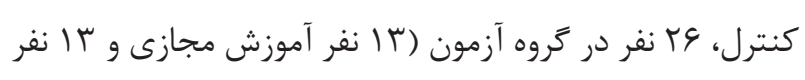

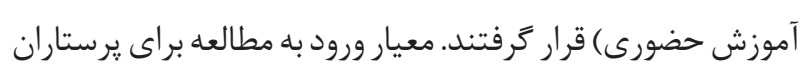
داشتن حداقل \& ماه سابقه كار در بخش اورزانس، تحصيلات دانشَاهى برستارى (كارشناسى و بالاتر)، عدم تصدى مسئوليت

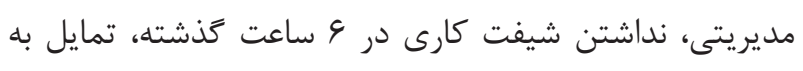

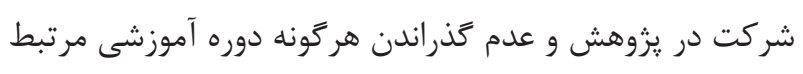

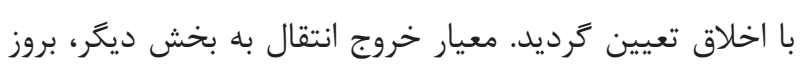

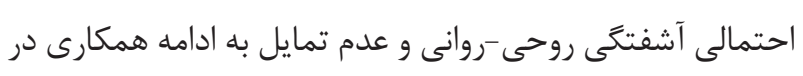
حين مطالعه بود. جهت كردآورى اطلاعات عملكرد اخلاقى از ابزار طراحى شده توسط دهقانى و همكاران استفاده شد ابزار رضايت مندى بيمار مربوط به بررسى رعايت معيارهاى اخلاق حرفهاى از

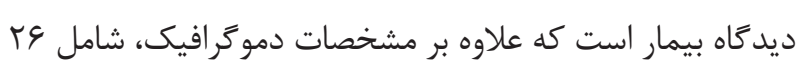

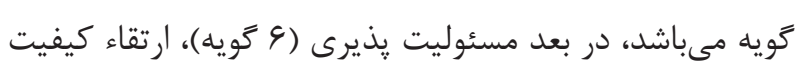

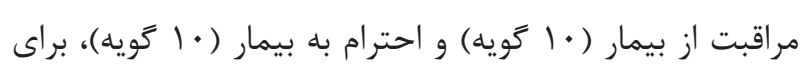

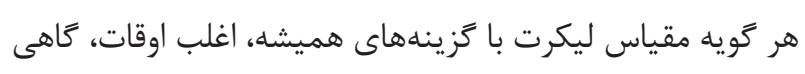
اوقات، به ندرت، هيج وقت در نظر كرفته شده است. نمره حداقل

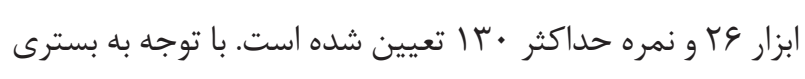

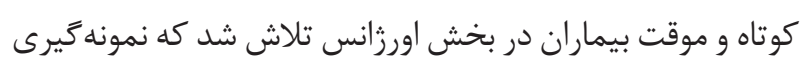
بيماران، در مرحله قبل و مراحل بعد از آزمون، از بيمارانى كه خصوصيات مشابه و نزديك به هم داشته باشند، انجام شود. ابزار

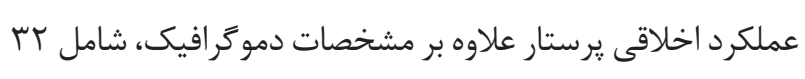

آنها در زمينه اخلاق حرفهاى، كيفيت مراقبت بهداشتى را به

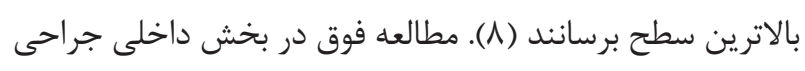

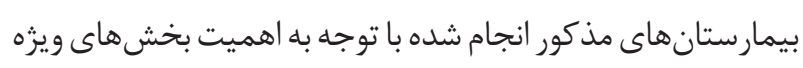

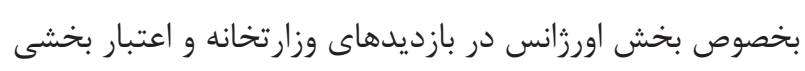

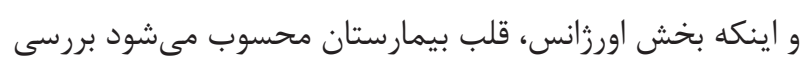

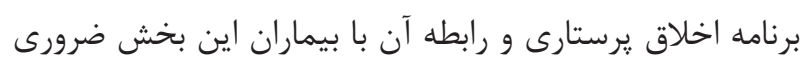

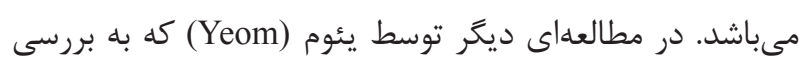
تأثير اخلاق بر حساسيت اخلاقى دانشجويان يرستارى يرداخته

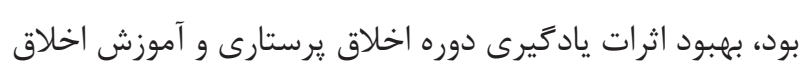

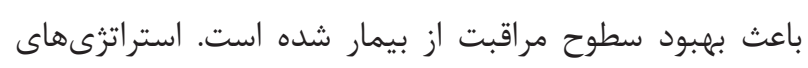
مؤثر آموزش اخلاق ترستارى جهت و توسعه برنامههاى اخلاقى با بـا

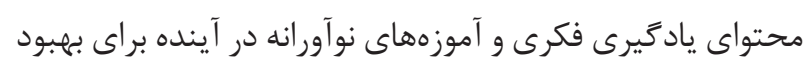

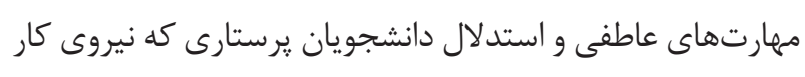

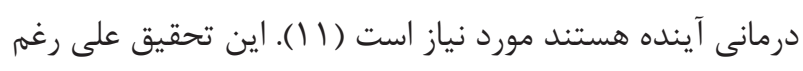

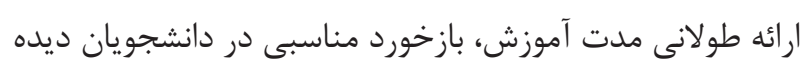

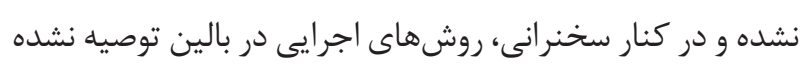

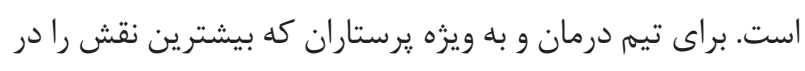

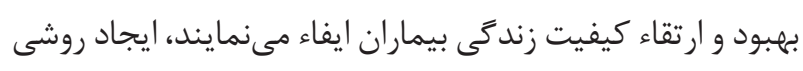

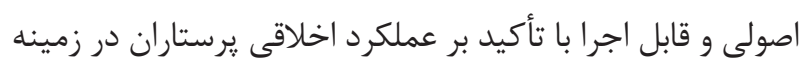
برنامه اخلاق حرفهاى بسيار ضرورى به نظر مىرسد. لذا، با توجه به ويزگى هاى خاص بيمارستان هاى نظامى شامل محيط، مر اجعه كنند

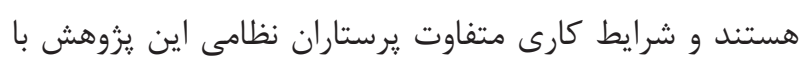
هدف تعيين تأثير برنامه اخلاق حرفهاى (حضورى و الكترونيك)

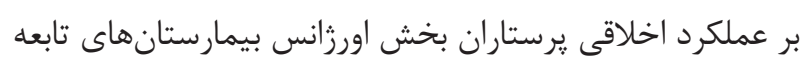
نيروهاى مسلح انجام شده است.

\section{مواد و روشها}

يزوهش حاضر از نوع مطالعه نيمه تجربى با طرح ييش-هو

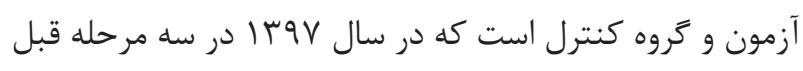

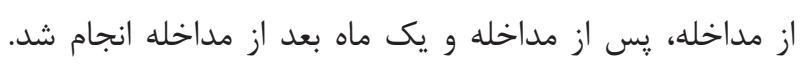

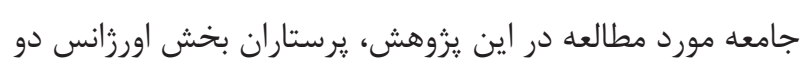

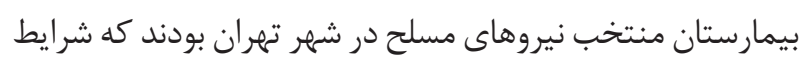

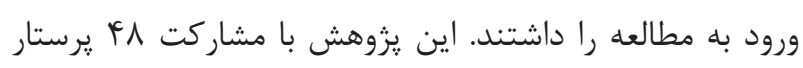


حضورى و غير حضورى الكترونيك، پس آزمون از يرستاران مورد آموزش به صورت حضورى توسط محقق انجام شد. به منظور

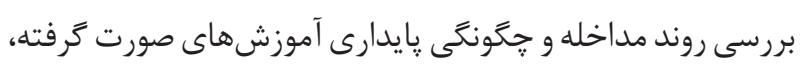

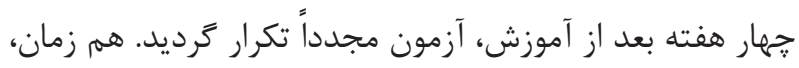

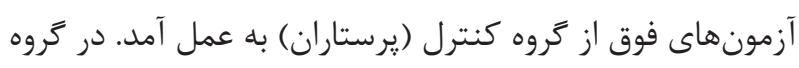

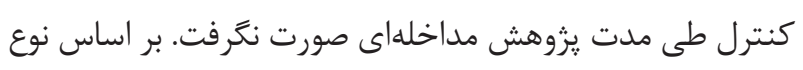

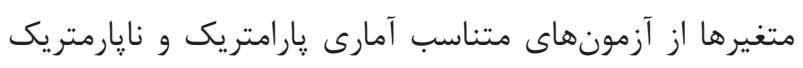

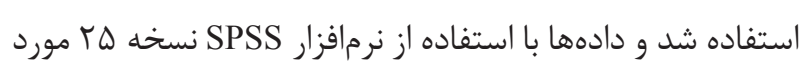

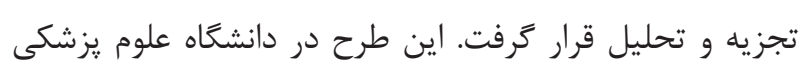
آجا به شماره

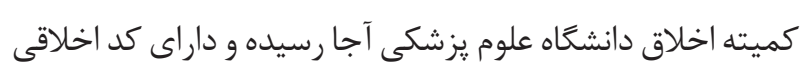

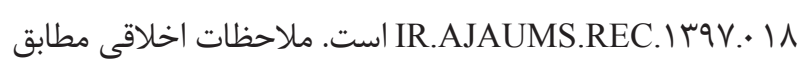
با بيانيه هلينسكى و كميته اخلاق نشر (COPE)، رعايت شده است.

\section{يافتهها}

دادهها مبتنى بر آزمون آمارى مناسب مورد تحليل قرار گرفتند.

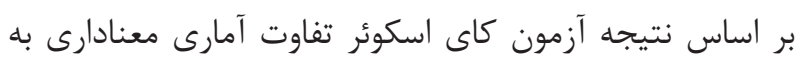

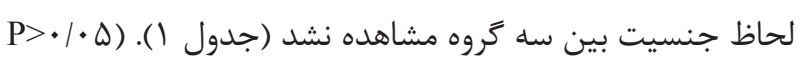

(Chi-Square=l/ $/$ A $\lambda$, df $=r$ بر اساس نتايج آزمون كاى اسكوئر متغيرهاى زمينهاى سابقه شغلى، وضعيت تأهل، سطح تحصيلات، وضعيت شغلى، جرخش إنش

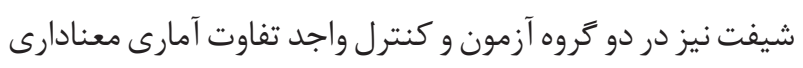

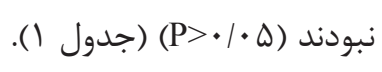

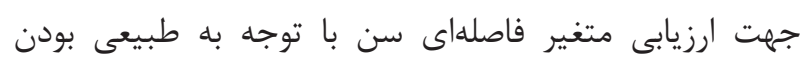

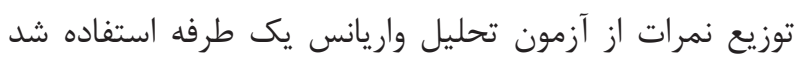

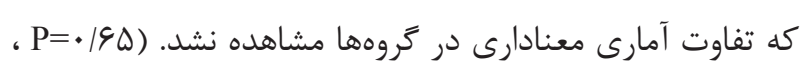

( ( $)(F(r / F \Delta)=r / q)$

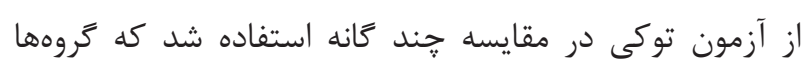
در مقايسه جفتى نيز تفاوت معنادارى به لحاظ سن نداشتند

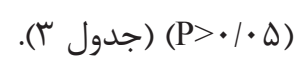

جهت بررسى نمرات حاصله از ابزار عملكرد اخلاقى در مرحله (جدوله ييش آزمون از آزمون آناليز واريانس يك طرفه (با توجه به نرمال

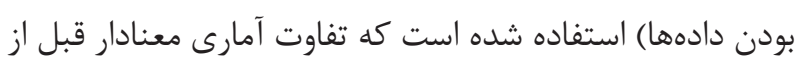

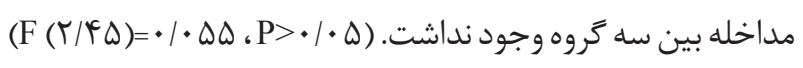

مراقبت از بيمار و كا گَويه در بعد احترام به بيمار، براى هر گويه مقياس ليكرت با گز ينههاى هميشه، اغلب اوقات، كاهى اوقات، به

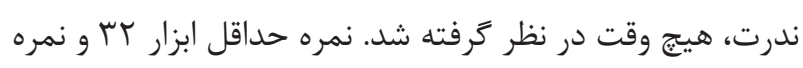

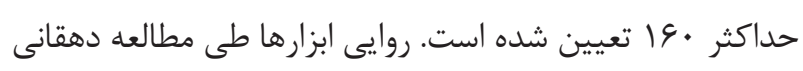

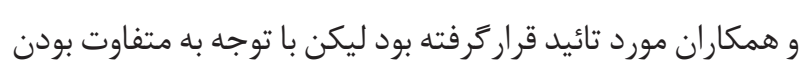

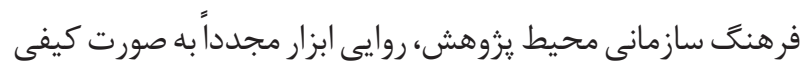

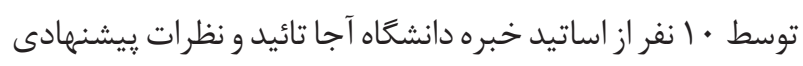
ايشان پس از تأييد توسط تيم تحقيق در گويهها اعمال شد (^).

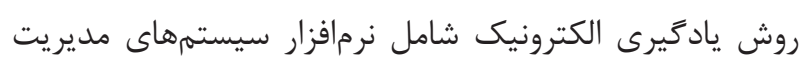

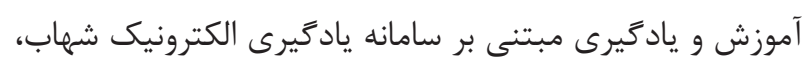

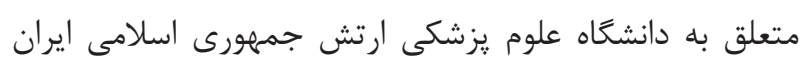

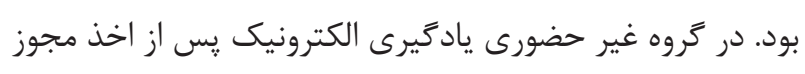

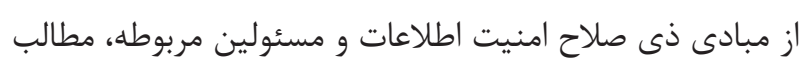

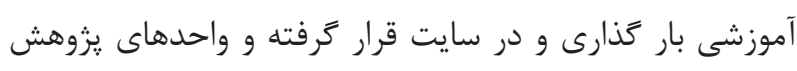
با توجه به نام كاربرى و رمز عبور اختصاصى خود وارى دور سارد مطالب آموزشى شده و پِ از مطالعه مباحث و ياسخ تَويى به سؤالات،

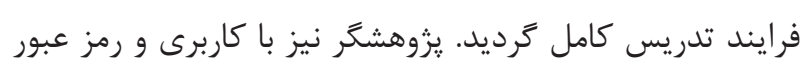

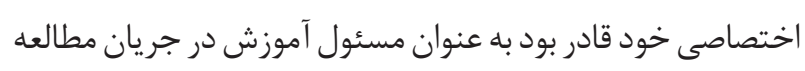

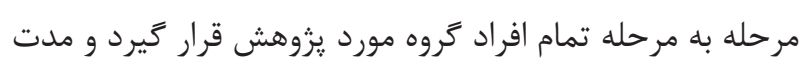
زمانى كه توسط شخص صرف مطالعه و جواب دهى به سؤه موالات

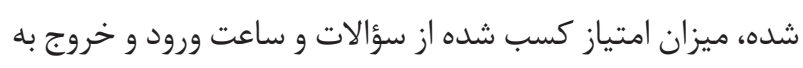

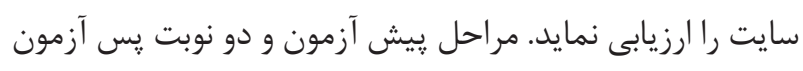
به صورت حضورى توسط محقق در بخش اورزانس انجام شد انجام

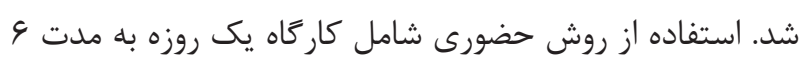

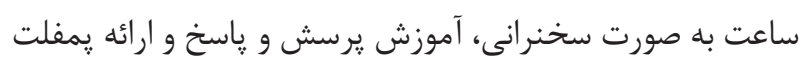

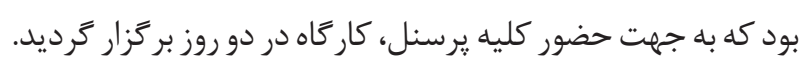

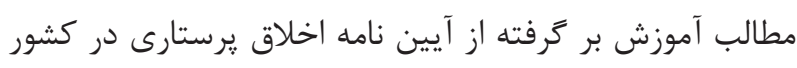

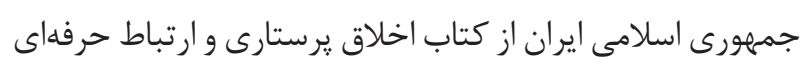
(1) (I )، شامل اصول اخلاقى در يرستارى (رعايت استقلال بيمار،

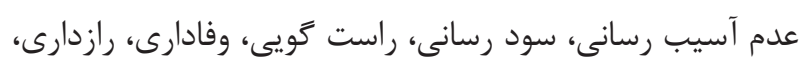

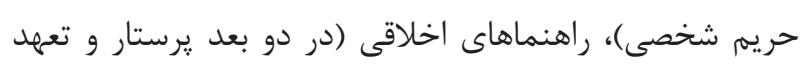

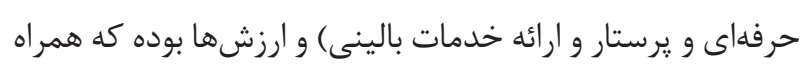

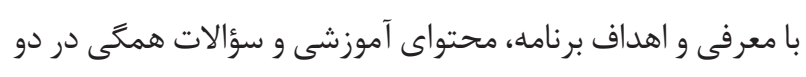
كروه يكسان تدوين گرديد. بعد از انجام مداخله به صورت آمداف آموزش 
جدول ا- بررسى توزيع فراوانى نسبى و مطلق يرستاران در دو كروه آزمون و كنترل

\begin{tabular}{|c|c|c|c|c|c|c|c|c|}
\hline \multirow{3}{*}{ آزمون كاى اسكوئر } & \multirow{2}{*}{\multicolumn{2}{|c|}{ كنترل }} & \multicolumn{4}{|c|}{ آزمون } & \multirow{3}{*}{\multicolumn{2}{|c|}{ متغير }} \\
\hline & & & \multicolumn{2}{|c|}{ آموزش مجازى } & \multicolumn{2}{|c|}{ آموزش حضورى } & & \\
\hline & درصد & تعداد & درصد & تعداد & درصد & تعداد & & \\
\hline \multirow{2}{*}{$\begin{array}{c}\mathrm{df}=\mathrm{r} \\
\mathrm{P}=\cdot / \uparrow q q\end{array}$} & $\Delta F / \Delta$ & ir & HN/D & $\Delta$ & $91 / 0$ & $\wedge$ & مرد & \multirow{2}{*}{ جنسيت } \\
\hline & $\varphi \Delta / \Delta$ & 1. & $91 / 0$ & $\Lambda$ & rN/D & $\Delta$ & زن & \\
\hline \multirow{4}{*}{$\begin{array}{c}\mathrm{df}=q \\
\mathrm{P}=\cdot / 19 \mathrm{r}\end{array}$} & $r T / V$ & $\Delta$ & $V / Q$ & 1 & · & · & كمتر از r سال & \multirow{4}{*}{ سابقه شغلى } \\
\hline & rI/A & v & $r \cdot / V$ & f & $V / Q$ & 1 & r-ט سال & \\
\hline & $1 \pi / 9$ & r & $r \cdot / V$ & f & $r \Lambda / \mathcal{F}$ & $\Delta$ & ه-••1 سال & \\
\hline & $\mathrm{r} / \mathrm{\Lambda}$ & V & $r \cdot / V$ & i & $\Delta r / \Lambda$ & V & بيش از • • سال & \\
\hline \multirow{2}{*}{$\begin{array}{c}\mathrm{df}=r \\
\mathrm{P}=\cdot / \Lambda \cdot r\end{array}$} & س & $\Lambda$ & $F \& / T$ & 4 & $r \cdot N$ & f & مجرد & \multirow{2}{*}{ وضعيت تأهل } \\
\hline & sT/V & 14 & $\Delta r / \Lambda$ & V & $49 / 4$ & 9 & متأهل & \\
\hline \multirow{2}{*}{$\begin{array}{c}\mathrm{df}=\mathrm{r} \\
\mathrm{P}=\cdot / / 1\end{array}$} & $9 \Delta / 4$ & TI & $V 9 / 9$ & 1. & $1 \cdots$ & IT & كارشناسى & \multirow{2}{*}{ تحصيلات } \\
\hline & $\varphi / 9$ & 1 & $r m$ & r & $\cdot$ & $\cdot$ & كارشناسى ارشد & \\
\hline \multirow{3}{*}{$\begin{array}{c}\mathrm{df}=f \\
\mathrm{P}=\cdot / / \Delta \Lambda\end{array}$} & $\Delta \cdot$ & 11 & $10 / 0$ & $r$ & $91 / 0$ & $\Lambda$ & كادر & \multirow{3}{*}{ وضعيت شغلى } \\
\hline & $\varphi / d$ & 1 & $\mathrm{~V} / \mathrm{S}$ & 1 & . & . & وظيفه & \\
\hline & $\varphi \Delta / \Delta$ & 1. & $\vee 9 / 9$ & 1. & $\Gamma \wedge / \Delta$ & $\Delta$ & قراردادى & \\
\hline \multirow{3}{*}{$\begin{array}{c}\mathrm{df}=\varphi^{f} \\
\mathrm{P}=\cdot / \cdot 9 \Lambda\end{array}$} & $\varphi \Delta / F$ & 1. & $10 / 0$ & $r$ & rN/G & $\Delta$ & صبح & \multirow{3}{*}{ وضعيت شيفت } \\
\hline & $11 / \mu$ & i & $\Delta r / \Lambda$ & V & $\Delta r / \Lambda$ & V & عصر و شب & \\
\hline & س & $\Lambda$ & $r \cdot / V$ & f & $V / 9$ & 1 & جرخشى & \\
\hline
\end{tabular}

جدول r - مقايسه سن يرستاران قبل از مداخله در تروهها

\begin{tabular}{|c|c|c|c|c|}
\hline \multicolumn{4}{|c|}{ تروه } & \multirow{3}{*}{ سن } \\
\hline \multirow{2}{*}{ 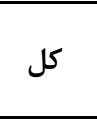 } & \multirow{2}{*}{ كنترل } & \multicolumn{2}{|c|}{ آزمون } & \\
\hline & & آموزش مجازى & آموزش حضورى & \\
\hline$\hat{~} \wedge$ & Tr & r & r & تعداد \\
\hline 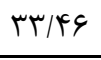 & m/Fi & rq/VV & rVITH & ميانگين \\
\hline$\Lambda / T \cdots$ & $9 / 111$ & $0 / \cdot 19$ & G/TAV & انحراف معيار \\
\hline $1 / 11 \mathrm{~F}$ & $r / .9 r$ & I/rqr & MYYF & خطاى استاندارد \\
\hline
\end{tabular}

جدول ץ- مقايسه سن برستاران در تروههاى مورد مطالعه

\begin{tabular}{|c|c|c|c|c|c|}
\hline & نتايج آزمون توكى & خطاى استاندارد & اختلاف ميانغين & \multicolumn{2}{|c|}{ كروه } \\
\hline & $\mathrm{P}=\cdot / \Gamma \Delta \mathrm{V}$ & $r / V \Delta$ & $-T / A T$ & حضورى & \multirow{2}{*}{ كنترل } \\
\hline & $\mathrm{P}=\cdot / \mathrm{Tq}$ & $r / V \Delta$ & r/GY & مجازى & \\
\hline & $\mathrm{P}=\cdot / \pi \Delta \mathrm{V}$ & T/VD & T/AT & كنترل & \multirow{2}{*}{ حضورى } \\
\hline & $P=\cdot|\cdot \Delta|$ & $r / \cdot 9$ & $V / 4 \&$ & مجازى & \\
\hline & $\mathrm{P}=\cdot /$ / १ & $T / V \Delta$ & $-M / G 4$ & كنترل & \multirow{2}{*}{ مجازى } \\
\hline$|f|$ & $\mathrm{P}=\cdot|\cdot \Delta|$ & $r / \cdot q$ & $-V / 4 \&$ & حضورى & \\
\hline
\end{tabular}


معنادارى بلافاصله بعد از مداخله وجود دارد ( ( • (P<) و بين گروه آموزش حضورى و آموزش مجازى تفاوت آمارى معنادارى مداف

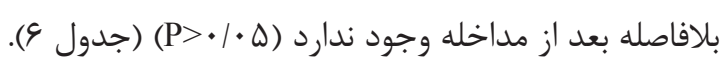

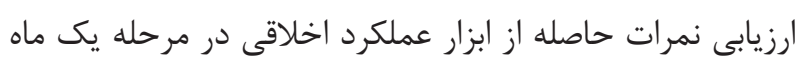

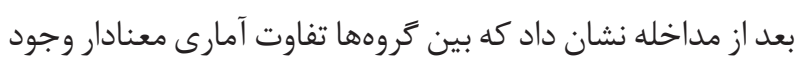

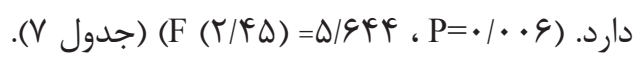

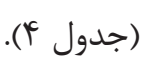
ارزيابى نمرات حاصله از ابزار عملكرد اخلاقى در مرحله بلافاصله

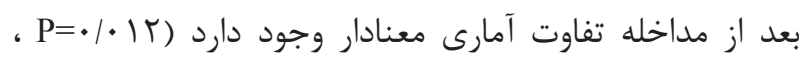
( $(F(T / F \Delta)=F / \Lambda F \Delta$

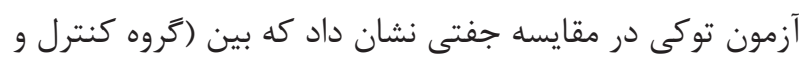

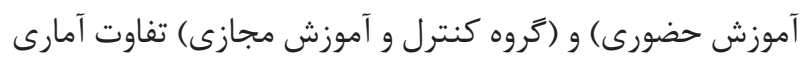
جدول F - مقايسه نمرات عملكرد اخلاقى يرستاران در كروهها قبل از مداخله

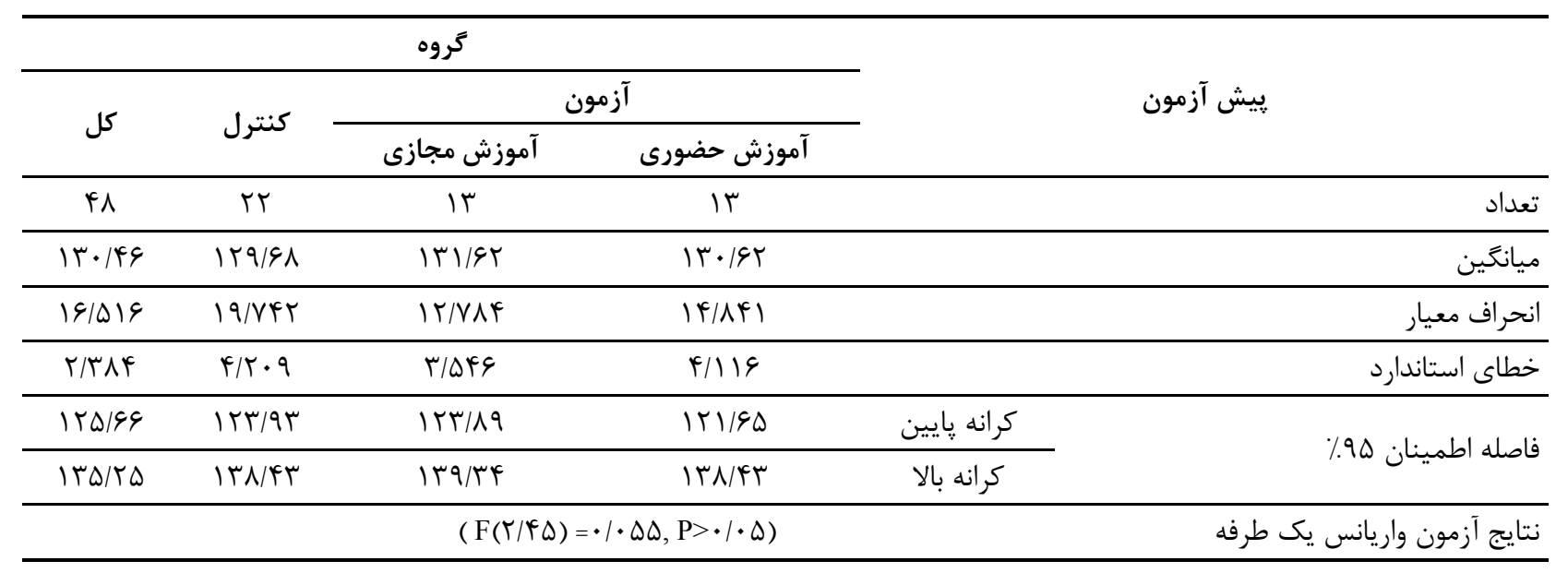

جدول هـ - مقايسه نمرات عملكرد اخلاقى يرستاران بلافاصله بعد از مداخله

\begin{tabular}{|c|c|c|c|c|c|}
\hline \multirow{3}{*}{ كل } & \multirow{3}{*}{ كنترل } & \multicolumn{2}{|c|}{ آزمون } & \multirow{3}{*}{\multicolumn{2}{|c|}{ يس آزمون اول }} \\
\hline & & \multicolumn{2}{|c|}{ آزمون } & & \\
\hline & & آموزش مجازى & آموزش حضورى & & \\
\hline$\uparrow \wedge$ & rt & 11 & Ir & & 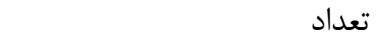 \\
\hline ITN/TV & $|r| / F \mid$ & $\mid f F / 10$ & $|F F| .$. & & ميانگين \\
\hline $\mid Q / 1 Q F$ & IN/TVG & N/VAr & $\Lambda / \uparrow \wedge \Delta$ & & انحراف معيار \\
\hline$r / 1 \wedge V$ & r/q1^ & r/Frg & r/ror & & خطاى استاندارد \\
\hline Irr/AV & ITr/Tg & ITN/AD & ITN/AV & كرانه يايين & فاصله اطمد \\
\hline $\mid F T / G V$ & $1 \% q / \Delta q$ & $\mid f q / 4 q$ & $\mid f q / 14$ & كرانه بالا & قاصله اطم \\
\hline & & $(F(\Gamma / \mathcal{F} \Delta)=F / \Lambda$ & $\cdot(\cdot \mid r)$ & & نتايج آزمون واريانس يك طرفه \\
\hline
\end{tabular}

جدول 9- مقايسه نمرات عملكرد اخلاقى برستاران در كروهها بلافاصله بعد از مداخله

\begin{tabular}{|c|c|c|c|c|}
\hline نتايج آزمون توكى & خطاى استاندارد & اختلاف ميانغين & كروه & \\
\hline $\mathrm{P}=\cdot 1 \cdot$ rq & $4 / 91$ & $-1 T / 09$ & حضورى & \multirow{2}{*}{ كنترل } \\
\hline $\mathrm{P}=\cdot / \cdot r \mathrm{~F}$ & $4 / 91$ & $-I T / V F$ & مجازى & \\
\hline $\mathrm{P}=\cdot / \cdot$ rq & $1 / 91$ & $1 \% / 09$ & كنترل & \multirow{2}{*}{ حضورى } \\
\hline $\mathrm{P}=1 / \cdots$ & $\Delta / \Delta \mid$ & $-\cdot / 1 \Delta F$ & مجازى & \\
\hline $\mathrm{P}=\cdot / \cdot r \mathrm{~F}$ & $p / q 1$ & $I T / V F$ & كنترل & \multirow{2}{*}{ مجازى } \\
\hline $\mathrm{P}=1 / \cdots$ & $\Delta / \Delta \mid$ &.$/ 1 \Delta F$ & حضورى & \\
\hline
\end{tabular}


جدول V- مقايسه نمرات عملكرد اخلاقى يرستاران يك ماه بعد از مداخله

\begin{tabular}{|c|c|c|c|c|c|}
\hline \multicolumn{4}{|c|}{ كروه } & \multirow{3}{*}{\multicolumn{2}{|c|}{ يك ماه بعد از مداخله }} \\
\hline \multirow{2}{*}{ كل } & \multirow{2}{*}{ كنترل } & \multicolumn{2}{|c|}{ آزمون } & & \\
\hline & & آموزش مجازى & آموزش حضورى & & \\
\hline$\uparrow \wedge$ & rt & IT & M & & 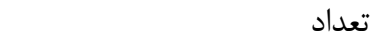 \\
\hline $149 / \vee 9$ & $|r| / G 4$ & $\mid f \Delta / V V$ & IFV/GT & & ميانگين \\
\hline $19 / 991$ & TI/TET & $N / I^{2}$ & $V / \cdot r \cdot$ & & انحراف معيار \\
\hline$r / F \Delta T$ & F/DHr & t/Ttt & $1 / 9 \Delta$ & & خطاى استاندارد \\
\hline ITY/AG & $|Y T / Y|$ & $14 \cdot / 94$ & $\mid F r / r V$ & كرانه پايين & \multirow{2}{*}{ فاصله اطمينان ه9٪٪ } \\
\hline IFF/VT & $|f| / \cdot 4$ & $10 \cdot|9|$ & $|0| / \Lambda 9$ & كرانه بالا & \\
\hline \multicolumn{5}{|c|}{ 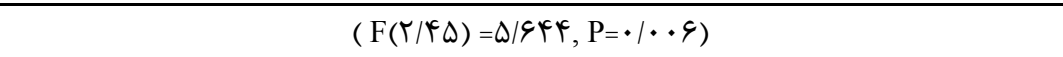 } & نتايج آزمون واريانس يك طرفه \\
\hline
\end{tabular}

در زروهها ايجاد شده است (I ( F جهت مقايسه جفتى (دو به دو) مراحل زمانى از آزمون تعقيبى بونفرونى (Bonferoni) استفاده شد. نتايج نشان داد كه در گروه كنترل در مرحله قبل، بلافاصله و يك ماه بعد از مداخله تفاوت

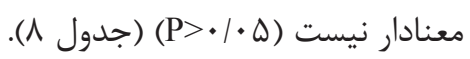

در مقايسه جفتى (دو به دو) از آزمون تعقيبى بونفرونى

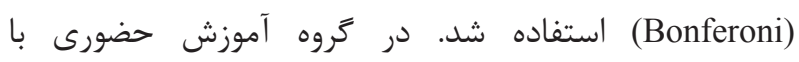
در مرحله قبل از مداخله و بلافاصله بعد از مداخله تفاوت معناداراست، ليكن بعد از مداخله و يكى ماه بعد تفاوت معنادار آمارى مشاهده نشد. در مقايسه جفتى (دو به دو) در گروه

آموزش مجازى نيز همين نتيجه حاصل شد (جدول 9).
بر اساس آزمون توكى مقايسه بين (كروه كنترل و آموزش حضورى) و (كروه كنترل و آموزش مجازى) تفاوت آمارى معنادار يك ماه بعد از مداخله وجود دارد ( ( • (P<) و كروه آموزش حضورى و آموزش مجازى تفاوت آمارى معنادار يك ماه بعد از مداخله وجود

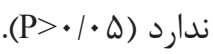
جهت ارزيابى روند اثركذارى مداخله از آزمون آناليز واريانس با اندازههاى تكرارى استفاده شد. در ابتدا با توجه به نتيجه آزمون

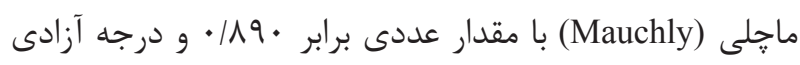
برابر r و ه • P> شد فرض كرويت (Test of Sphericity) دادهها اثبات گرديد. آزمون درون گروهى نشان دهنده تفاوت معنادار بوده و تغيير در ميانخين نمره عملكرد اخلاقى يرستارى طى سه زمان

جدول ^- شاخصهاى جند گَانه گَروهها بر حسب زمانهاى قبل، بعد و يك ماه بعد از مداخله

\begin{tabular}{|c|c|c|c|c|c|c|}
\hline \multirow{2}{*}{ P(سطح معنى دارى) } & \multicolumn{2}{|c|}{ فاصله اطمينان ه9٪٪ } & \multirow{2}{*}{ خطاى استاندارد } & \multirow{2}{*}{ ميانگين } & \multirow{2}{*}{ 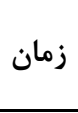 } & \multirow{2}{*}{ كروه } \\
\hline & حد بالا & حد يايين & & & & \\
\hline $1 / \cdots$ & IrG/9r & $I T Y / F F$ & $r / \Delta q$ & $1 r 9 / 9 \wedge$ & 1 & \\
\hline$\cdot|\cdot|+\mid$ & $I M V / F F$ & $I T \Delta / T V$ & $r / 99$ & $\| \pi \mid / F$. & r & كنترل \\
\hline$\cdot 1 \cdot 10$ & IrN/K. & $\mid r F / 9 G$ & 要 & r & r & \\
\hline $1 / \cdots$ & $\mid r \cdot / \cdot r$ & $171 / 19$ & $F / \& V$ & $|r \cdot| 9 \mid$ & 1 & \\
\hline$\cdot|\cdot|+\mid$ & $101 / \mathrm{AF}$ & $\mid r \varepsilon / 10$ & ऍ/^ & $|F F| \cdots$ & r & آموزش حضورى \\
\hline$\cdot 1 \cdot 10$ & $109 / 9 T$ & IrN/qr & $f / r$. & $|F V| q \mid$ & r & \\
\hline $1 / \cdots$ & $|f| / \cdot r$ & $1 T r / 19$ & $F / 9 V$ & $|\Pi| / 9 \mid$ & 1 & \\
\hline$\cdot / \cdot r \Lambda$ & $\mid \Delta r / \cdots$ & $\mid \Pi G / \mu$. & ऍ/^q & $|F F /| \Delta$ & r & آموزش مجازى \\
\hline \multirow[t]{2}{*}{$\cdot / \cdot r \Lambda$} & $\mid \Delta F / F F$ & $\mid r V / \cdot q$ & $\boldsymbol{r} / \mu$. & IFD/VG & r & \\
\hline & \multicolumn{3}{|c|}{$\mathrm{F}=\uparrow \wedge / \Delta \Delta \uparrow, \mathrm{P}<\cdot \mid \cdots 1$} & & & نتايج آزمون واريانس با اندازههاى تكرارى \\
\hline
\end{tabular}




\begin{tabular}{|c|c|c|c|c|c|c|c|}
\hline \multicolumn{2}{|c|}{$৭ ৯ \%$ Confidence Interval for Difference } & \multirow{2}{*}{$\begin{array}{c}\text { معنادارى } \\
\text { P }\end{array}$} & \multirow{2}{*}{ 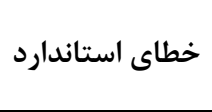 } & \multirow{2}{*}{ تفاوت ميانگينها } & \multirow{2}{*}{\multicolumn{2}{|c|}{$\begin{array}{l}\text { زمان (I) زمان (J) } \\
\text { زمان }\end{array}$}} & \multirow{3}{*}{ 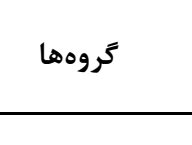 } \\
\hline كرانه بالا & كرانه يايين & & & & & & \\
\hline T/AVT & -G/TTV & $1 / \cdots$ & $1 / \wedge \Delta$ & $-I / V Y V$ & $r$ & 1 & \\
\hline$r / \varepsilon \wedge \Delta$ & $-9 / 090$ & $\cdot / 9 \cdot 1$ & 1/1ब9 & $-1 / 9 \Delta \Delta$ & $r$ & & \multirow{5}{*}{ كنترل } \\
\hline G/TrV & -r/AVT & $1 / \cdots$ & $1 / \wedge \Delta \cdot$ & I/VTV & 1 & \multirow{2}{*}{$r$} & \\
\hline$r / T V$. & -r/VYD & $1 / \cdots$ & $1 / 4 \cdot \varphi$ & -./TTV & r & & \\
\hline $9 / 090$ & $-r / \varphi \wedge \Delta$ & $\cdot / 9 \cdot 1$ & 1/149 & $1 / 9 \Delta \Delta$ & 1 & \multirow{2}{*}{ r } & \\
\hline r/VTd & $-r / T V$ • & $1 / \cdots$ & $1 / 4 \cdot 9$ & . ITTV & $r$ & & \\
\hline$-V / F \cdot 1$ & $-19 / r \& \wedge$ & $\cdot 1 \cdot$ & $r / \varphi \cdot \varphi$ & - & $r$ & 1 & \multirow{6}{*}{ 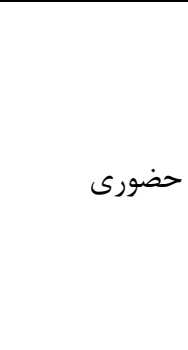 } \\
\hline$-1 \cdot 1994$ & 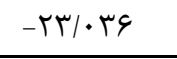 & $\cdot 1 \cdots$ & T/FTV & $-|V| \cdots$ & r & 1 & \\
\hline $19 / \% 4 \wedge$ & $V / \mathbb{4} \cdot 1$ & $\cdot 1 \cdots$ & $r / 4 \cdot \varphi$ & $\mid r / r \wedge \Delta$ & 1 & $r$ & \\
\hline.$/ 9 M F$ & $-\Lambda / 190$ & .1194 & $1 / 149$ & $-r / 910$ & r & 1 & \\
\hline r & $1 \cdot 1948$ & $\cdot 1 \cdots$ & T/FTV & $\mid \mathrm{V} / \cdots$ & 1 & \multirow{2}{*}{$r$} & \\
\hline $1 / 190$ & $-\cdot / 9 \mu \mathrm{F}$ &.$/ 194$ & $1 / 149$ & $r / 9 \mid \Delta$ & $r$ & & \\
\hline$-9 / \Delta \Delta \Delta$ & $-I N / D Y Y$ & $\cdot 1 \cdots$ & $r / \boldsymbol{r} \cdot \varphi$ & $-I T / \Delta H \wedge$ & $r$ & \multirow{2}{*}{1} & \multirow{6}{*}{ آموزش مجازى } \\
\hline$-\Lambda / 11 \wedge$ & $-r \cdot / 19$. & $\cdot 1 \cdots$ & T/ETV & $-|F /| \Delta f$ & $r$ & & \\
\hline IN/DYT & $9 / \Delta \Delta \Delta$ & $.1 \cdots$ & $r / 4 \cdot G$ & IT/QKA & 1 & \multirow{2}{*}{$r$} & \\
\hline T/QTF & $-9 / 190$ & $1 / \cdots$ & $1 / 149$ & $-1 / 910$ & $r$ & & \\
\hline 1.119. & $1 / 111$ & $.1 \cdots$ & T/FTV & $|f /| \Delta f$ & 1 & \multirow{2}{*}{ r } & \\
\hline $9 / 190$ & $-r / q \mu F$ & $1 / \cdots$ & $1 / 149$ & $1 / 910$ & $r$ & & \\
\hline
\end{tabular}

جدول • (1- بررسى آزمون بين تروهى

\begin{tabular}{|c|c|c|c|c|c|}
\hline مربع اتا ( Eta Squar) & سطح معنى دارى (P) & مقدار آماره (F) & ميانغين مربعات & درجه آزادى & مجموع مربعات \\
\hline$\cdot 11 \cdot r$ & $\cdot 1 \cdot \wedge \Lambda$ & T/DSA & $19 \wedge 9 / \cdot 11$ & $r$ & rrVh/·rg \\
\hline
\end{tabular}

بحث و نتيجه يزوهش حاضر با هدف تعيين تأثير برنامه اخلاق حرفهاى (حضورى و الكترونيك) بر عملكرد اخلاقى يرستاران بخش اورزانس بيمارستانهاى تابعه نيروهاى مسلح انجام شده است. نتايج اين يزوهش نشان داد در زمينه تعيين و مقايسه تأثير برنامه اخلاق حرفهاى (حضورى و مجازى) بر عملكرد يرستاران قبل و بعد از مداخله، تفاوت آمارى معنادار در نمره عملكرد يرستاران قبل از مداخله، در زروه آزمون و كنترل وجود نداشت. در مرحله يس آزمون اول (بلافاصله بعد از مداخله) و يس آزمون دوم (يكى ماه بعد از مداخله) تفاوت آمارى معنادار در زروه آموزش حضورى و الكترونيك وجود دارد لذا، مداخله در هر دو گروه آزمون تأثير گذار
در آزمون بين گروهى بر حسب زمان با توجه به نتيجه آناليز واريانس با اندازههاى تكرارى در سه گروه كنترل و آموزش حضورى و آموزش مجازى با ه • P> Pناوت معنادار آمارى مشاهده نشد.

(جدول (ج) (جورن)

جدول || - بررسى اندازه اثر مداخله بر عملكرد اخلاقى ير ستاران بلافاصله بعد از مداخله و يك ماه بعد از مداخله در تروه آنداز آزمون

\begin{tabular}{|c|c|c|}
\hline ارزشيابى & اندازه اثر (d) & عَروه يرستاران \\
\hline متوسط & . / & يس آزمون اول \\
\hline متوسط & $\cdot 10 \cdot 1$ & ֶس آزمون دوم \\
\hline
\end{tabular}


اخلاق يرستارى تأثير مثبتى بر رعايت حقوق بيماران در بخش

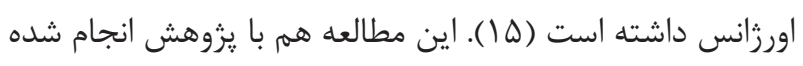

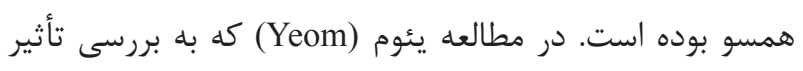

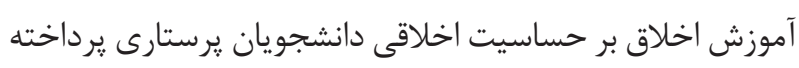

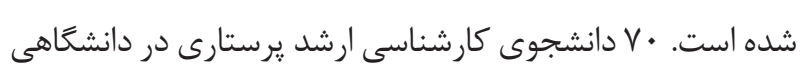

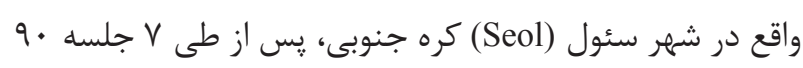

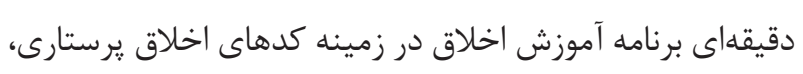
تصميم گيرى اخلاقى، يروسه هاى حرفهاى ساختن يرستارى انجام

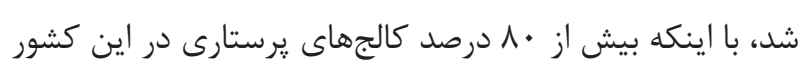

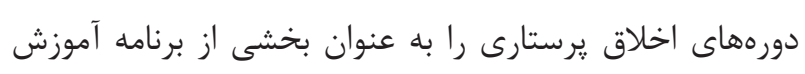

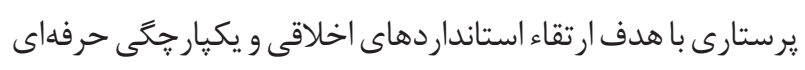

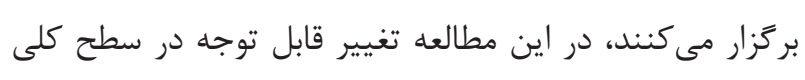
حساسيت اخلاقى دانشجويان وجود نداشت. ولى در مراقبت بيمار محور، افزايش حساسيت اخلاقى وجود داشته به طورى كه آموزش دانش اخلاق يرستارى تأثير مثبتى بر ايده دانشجويان در مورد احترام

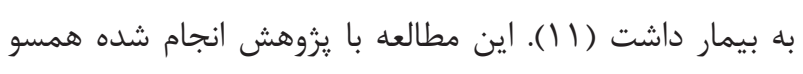

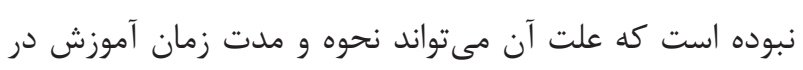

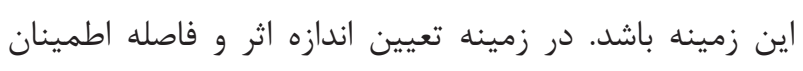

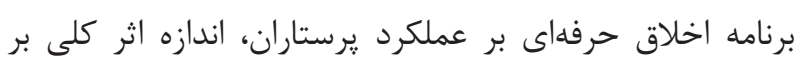

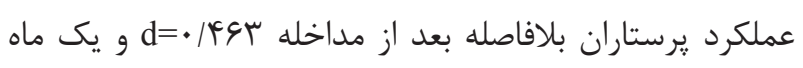

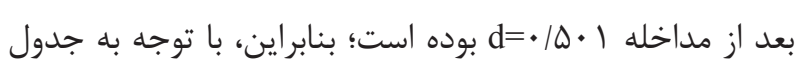

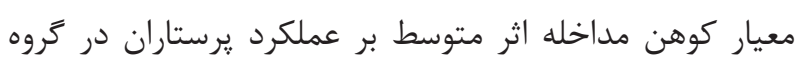
آزمون داشته است. در مطالعه قبادى فر و همكاران با عنوان مدان

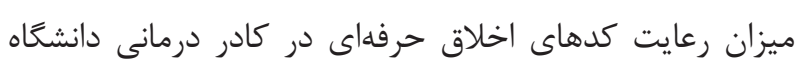

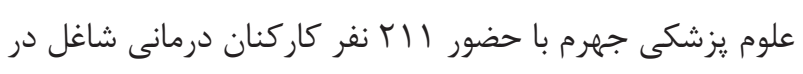
1 بخش دو بيمارستان شهر جهرم رعايت كلى كدهاى اخلاقى از

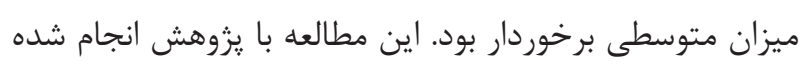

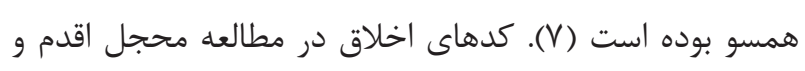

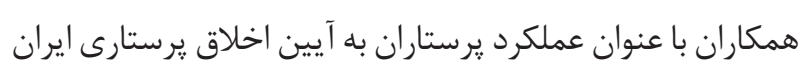

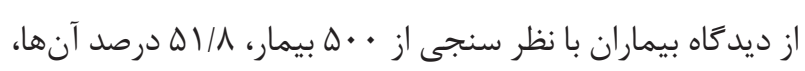

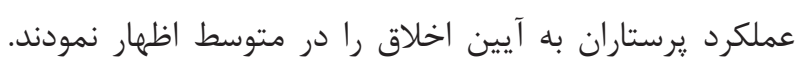

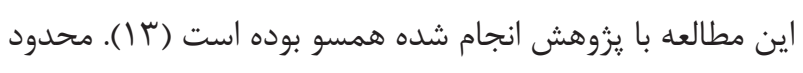

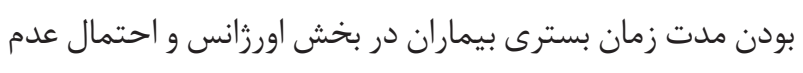

بوده است. در مقايسه بين كروه (كنترل و آموزش حضورى) و (كنترل و آموزش مجازى) تفاوت آمارى معنادار بلافاصله و يكى ماه

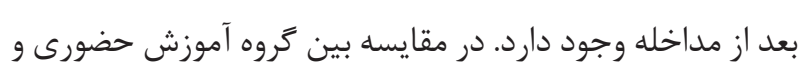

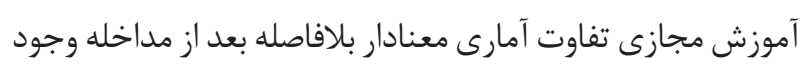

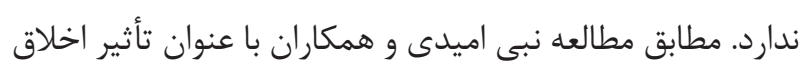

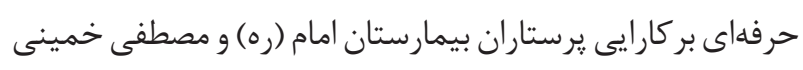

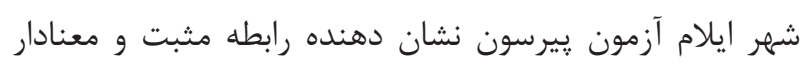

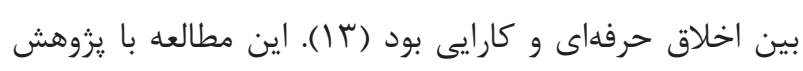
انجام شده همسو بوده است. مطابق با مطالعه نوحى و همكاران با عنوان بررسى نكرش و عملكرد دانشجويان، مديران و مدرسان

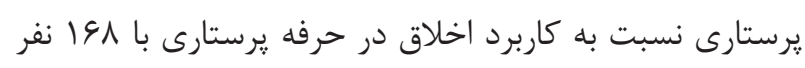

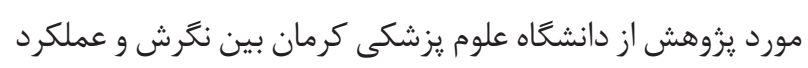

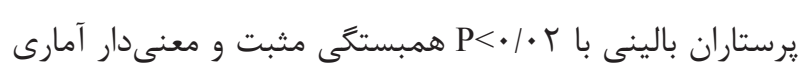

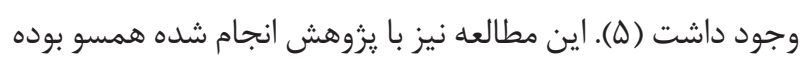

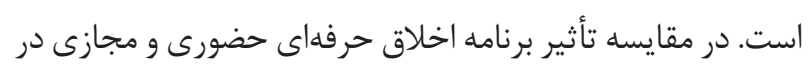

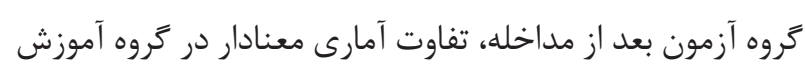

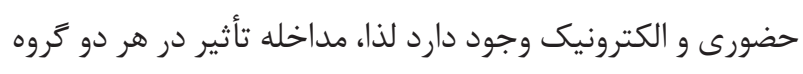

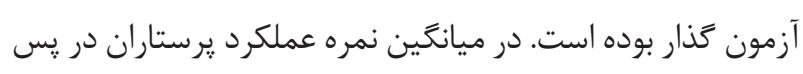

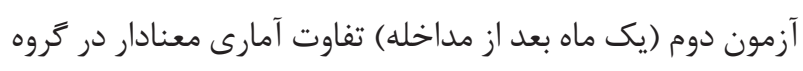

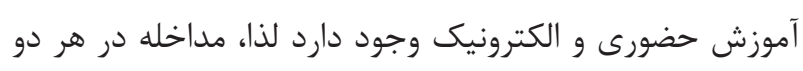
كروه آزمون تأثير كذار بوده است. مطالعه دهقانى و همكاران با عنوان رعايت معيار اخلاق حرفهاى در عملكرد يرستارى از ديد كاه

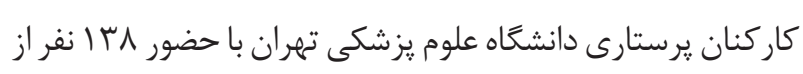

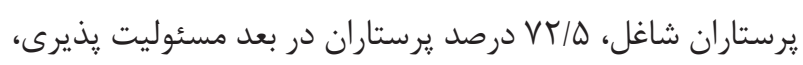

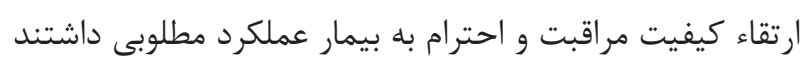
و بين نوبت كارى و كيفيت عملكرد حرفهاى يرستارى همبستكى دئى

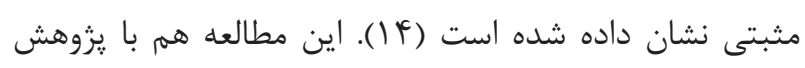

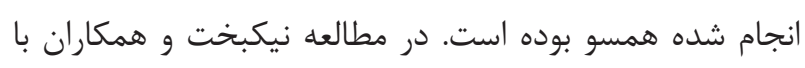
عنوان بررسى تأثير كاركاه اخلاق يرستارى بر رعايت حقوق بيمار

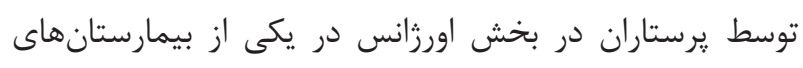

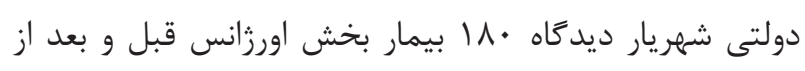

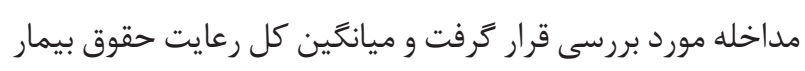

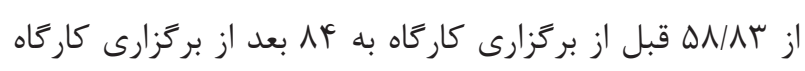

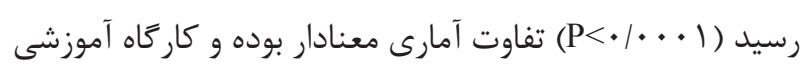




$$
\text { مناسب جهت تكميل ابزار، عدم امكان تخصيص تصادفى گروههاى }
$$

\section{تشكر و قدردانى}

اين مقاله بخشى از يايان نامه يرستارى اورزانس براى دريافت درجه كارشناسى ارشد است كه در دانشعاه علوم يزشكى آجا به شماره

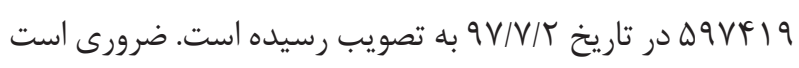
از تمام افرادى كه در انجام اين تحقيق يارى گر ما بودند تشكر نمايم به ويزه يرستاران محترم مشاركت كننده در اين يثوهش كه در بخش اورزانس بيمارستان نيروهاى مسلح به بيماران خدمت رسانى مى نمايند.

\section{تضاد منافع}

نويسند

$$
\text { يزوهش وجود نداشته است. }
$$

\section{References}

1- Bostani S. Strategies to promote professional ethics in nursing education system. Development Strategies in Medical Education. 2015;2(2):13-22.

2- Khaki S, Esmaeilpourzanjani S, Mashoof S. The relationship of ethical observance of nurses with quality of care from patient's point of view. J Clinical Nursing and Midwifery. 2016;5(1):1-11.

3- Milliken A, Grace P. Nurse ethical awareness: Understanding the nature of everyday practice. Nurs Ethics. 2017;24(5):517-24. DOI: 10.1177/0969733015615172 PMID: 26659025

4- Foroughi S, Alhani F, Kazemnejad A, Zareian A. Explaining the Role of Values in Professional Nursing Ethics: A Comprehensive Study. Yafte J Med Sci. 2017;18(1):56-64.

5- Nouhi S, Ghana S, Jouybari L, Kalantari S. Evaluating attitudes and performance of nursing students, teachers, managers towards ethics in nursing profession. Quarterly J Education and Ethics in Nursing. 2016;5(2):1-7.

6- Mohajjel-Aghdam A, Hassankhani H, Zamanzadeh V, Khameneh S, Moghaddam S. Knowledge and Performance about Nursing Ethic Codes from Nurses' and Patients' Perspective in Tabriz Teaching Hospitals, Iran. J Caring Sci. 2013;2(3):219-27. DOI: 10.5681/jcs.2013.027 PMID: 25276730

$$
\begin{aligned}
& \text { كروههاى آزمون و كنترل، ازدحام بخش اورزانس، احتمال مشاركت } \\
& \text { ناكامل نمونهها جهت حضور در كلاس با توجه به جرخشى بودن } \\
& \text { شيفتها و مدت زمان كوتاه اقامت بيماران در بخش اورزانس از } \\
& \text { موارد محدوديت اين يثوهش مىباشد. }
\end{aligned}
$$

به طور كلى نتايج اين مطالعه نشان داد به كاركيرى آموزش اخلاق حرفهاى به هر دو روش حضورى و مجازى تأثير مثبتى بر عملكرد اخلاقى يرستاران اورزانس دارد ولى با توجه به نتايج به دست آمده

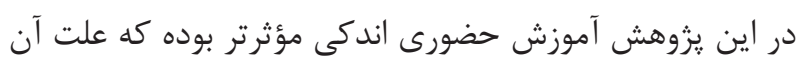
مى تواند برقرارى رابطه جهره به جهره و تعامل بين طرفين باشد و مورد بعد اينكه استفاده از فضاى مجازى براى آموزش هنوز به طور كامل توسط مديران و يرسنل مورد قبول واقع نشده است. لذا، با توجه به نتايج به دست آمده از مطالعات همسو ييشنهراد مىشود تلاش بيشترى براى ارتقاء شايستخى اخلاقى :برستاران در دوره آموزش رسمى و ضمن خدمت صورت كيرد. همجنين آكاهى مديران يرستارى از اين يافتهها مىتواند در برنامهريزى دورى مؤثر نيروى انسانى و ارتقاء اخلاق حرفهاى راه كَشا باشد. محدوديتها و مشكلات تحقيق شامل، محدود بودن مدت زمان بسترى بيماران در بخش اورزانس و امكان احتمالى عدم تمركز

7- GHobadi Far MA, Mosalanejad L. Evaluation of staff adherence to professionalism in Jahrom University of Medical Sciences. Education \& Ethic in Nursing. 2013;2(2):1-10.

8- Dehghani A, Radbeh F, Parviniannasab AM, Khaki S, Shamsizadeh M, Beyramijam M. Enactment of professional ethics standards compliance in patients and nurses prospective. J Holistic Nursing And Midwifery. 2015;25(4):64-72.

9- Stolt M, Leino-Kilpi H, Ruokonen M, Repo H, Suhonen R. Ethics interventions for healthcare professionals and students: A systematic review. Nurs Ethics. 2018;25(2):133-52. DOI: 10.1177/0969733017700237 PMID: 28393607

10- Fareghzadeh N, Kashi A. An Evaluation Of Virtual Education Methods And Tools To Improve Teaching Quality From the point of view of the Faculty Members of Islamic Azad University of Khodabandeh. Journal Managment System. 2014;5(1):121-52.

11- Yeom HA, Ahn SH, Kim SJ. Effects of ethics education on moral sensitivity of nursing students. Nurs Ethics. 2017;24(6):644-52. DOI: 10.1177/0969733015622060 PMID: 26811393

12- Bagheri E, Gholaghaie F, Matouripour P. Nursing Ethics and Professional Communication. Tehran: Haidari; 2016.

13- Omidi N, Asgari H, Omidi M. The relationship between 
professional ethics and the efficiency of the nurses employed in Imam Hospital and Mostafa Khomeini Hospital in Ilam. Iranian Journal of Medical Ethics and History of Medicine. 2016;9(3):6573.

14- Dehghani A, Dastpak M, Gharib A. Barriers to respect professional ethics standards in clinical care; viewpoints of nurses. Iranian
Journal of Medical Education. 2013;13(5):421-30.

15- Nikbakht Asrabadi 1, Bozorgzad P, Yekaninejad M, Jafarloo A, Rahmati M. Effect of nurssing ethis workshop on the rights of patient in the emergencydepartment. Iranian Journal of Cardiovascular Nursing. 2015;4(3):6-15. 